\title{
Last Gasp
}

Rank of doctors among professions with most bacteria in their work environments: 5

Rank of accountants: 2

No. of spoons an office lunch room will have to buy in a year to ensure always having 70 on hand: 250

No. of vacation days taken by the average Canadian worker in 2006: 19

No. of vacation days taken by the average French worker in 2006: 39

Estimated number of hours the Canadian economy loses annually due to insomnia: 48000000

Percentage increase in 10-pin bowling scores attained by subjects exposed to the scent of jasmine: 27

No. of percentage points by which each daughter in a family raises the likelihood

of parents voting for a left-leaning political party: 2

Percentage of liberal women who say they dream about same-sex encounters: 14

Percentage of conservative women who say so: 4

No. of seconds it takes a university-age man to become sexually aroused when exposed to pornography: 30

No. of seconds it takes a university-age woman: 30

Proportion of Canadian women who say, in a first encounter with a man, that they prize wit over looks: $3 / 4$

Proportion of Canadian men who say, in a first encounter with a woman, that they prize looks over intelligence: $3 / 5$

Percentage by which the human head and face have shrunk over the past 10000 years: 30

No. of years younger an affluent, 40-something married woman who has avoided excessive sun exposure

will appear compared to a single, jobless woman who has devoted too much time to tanning: 7.2

No. of years younger an affluent, 40-something married man with no more than 3 children

will appear as compared with a single, jobless man who has reduced his body mass index by 2 points: 10

Average number of years it would take a person eating a raw egg a day

to fall ill with salmonella poisoning: 55

No. of excess cancer deaths per 100 ooo people who eat farmed salmon: 24

Reduction in number of deaths from heart disease per 100000 people

among those who regularly eat any kind of salmon: 7125

Gallons of water it takes to produce $250 \mathrm{~g}$ of beef: 8000

No. of grams of salt in a Big Mac served in Canada: 2.55

No. of grams of salt in a Big Mac served in Portugal: 0.50

Percentage of Canadians, given current sodium intake, who will develop hypertension: 95

Average weight of an American woman, age 20-29, in 1960, in kg: 64

Average weight of an American woman, age 20-29, today, in kg: 77

Average weight of a Montreal Canadiens hockey player in 1917, in kg: 75

Average weight of a Montreal Canadiens hockey player in 2003, in kg: 92

Percentage of American Baptists who are considered obese: 30

Percentage of Canadian Baby Boomers who are considered obese: 30

Percentage of Americans with no religious affiliation who are considered obese: 6

Percentage increase in hip and knee replacement surgeries 1995-2005: 87

Percentage of patients receiving artificial knees who were overweight or obese: 87

Percentage of Canadians who believe their weight has little or no effect on their heart health: 58

Percentage increase in positive health outcomes of heart-bypass surgery patients being prayed for by others: 0

Percentage of Canadians who listen to a weather report before leaving home: 93

Percentage increase in heart attacks for every 10-degree drop in temperature: 13

No. of polar bears resident in the Greater Toronto Area who succumbed to West Nile virus in 2006: 1

A list of sources is available at www.cmaj.ca/cgi/content/full/175/12/1648/DC1

Compiled by David McDonald, an Ottawa filmmaker and writer. 